\title{
Balkanologie
}

Balkanologie Revue d'études pluridisciplinaires

Vol. IX, n' $1-2 \mid 2005$

Volume IX Numéro 1-2

\section{Western Thracian Muslims in Athens}

From Economic Migration to Religious Organization

Les musulmans de Thrace occidentale à Athènes : de la migration économique à

l'organisation religieuse

\section{Dimitris Antoniou}

\section{(2) OpenEdition}

Journals

Édition électronique

URL : http://journals.openedition.org/balkanologie/579

DOI : 10.4000/balkanologie.579

ISSN : 1965-0582

\section{Éditeur}

Association française d'études sur les Balkans (Afebalk)

\section{Édition imprimée}

Date de publication : 1 décembre 2005

ISSN : 1279-7952

\section{Référence électronique}

Dimitris Antoniou, « Western Thracian Muslims in Athens », Balkanologie [En ligne], Vol. IX, nº 1-2 I 2005, mis en ligne le 13 janvier 2010, consulté le 17 décembre 2020. URL : http://

journals.openedition.org/balkanologie/579; DOI : https://doi.org/10.4000/balkanologie.579 


\title{
WESTERN THRACIAN MUSLIMS IN ATHENS : FROM ECONOMIC MIGRATION TO RELIGIOUS ORGANIZATION
}

\author{
Dimitris Antoniou*
}

\section{INTRODUCTION : TROUBLES WITH WORDS ${ }^{1}$}

Scholars often start their analyses of the minority population of Western Thrace with demographics. For these authors, it seems of crucial importance that the reader knows that this population is divided into three distinct groups which in turn can be counted in absolute numbers. In one of his latest works on the topic, Baskin Oran provides us with the following information : " this profoundly religious minority of $110000-$ is composed of approximately 70000 Muslims of Turkish ethnic origin, 35 000 Pomaks (slavophone Muslims) and 5000 Muslims of Romany ethnic origin $n^{2}$. However, another scholar provides slightly different estimations and uses slightly different terms. According to Yorgos Christides, in 1993, the Greek state estimated the number of "Muslims" living in Western Thrace to 114000 , and clarified that $50 \%$ of them were of "Turkish origin", 35\% were "Pomaks" and $15 \%$ were "Athingani"3. But, even it seems easy to understand who the people of "Turkish

\footnotetext{
- Oxford-Princeton Research Project : Culture and Religions of the Eastern Mediterranean World. Contact: dimitris.antoniou@orinst.ox.ac.uk
}

${ }^{1}$ The list of friends and colleagues who read this article is so long as to embarrass me. Nevertheless I should mention with gratitude the advice and guidance of Celia Kerslake, Yahya Michot, Richard Clogg, Olga Demetriou, Renée Hirschon, Aspasia Papadopoulou, Kerem Oktem and Reem Abou El-Fadl, all from Oxford University. Likewise I most gratefully acknowledge the critical interest of my mentors and colleagues from Harvard University's Center for Hellenic Studies Gregory Nagy, Jennifer Reilly, Anna Stavrakopoulou as well as the assistance and support I received from Haldun Gulalp, Xavier Bougarel Tassos Costopoulos and Dimitris Trimis.

${ }^{2}$ Oran (Baskun), "The Story of Those Who Stayed. Lessons From Articles 1 and 2 of the 1923 Convention" in Hirschon (Renée), Crossing the Aegean : An Appraisal of the 1923 Compulsory Population Exchange between Greece and Turkey, Oxford : Berghahn, 2003, P. 98.

3 Christides (Yorgos), "The Muslim Minority in Greece ", in Niblock (Tim), Nonneman (Gerd), Szajkowski (Bogdan), eds., Muslim Communities in the New Europe, Berkshire : Ithaca Press, 1996, p. 135. 
origin" are, who are the "Pomaks", the Roma and the "Athingani" ?

These sorts of questions inevitably require an examination of a set of definitions. Such an examination is essential, since, having undertaken to work with such terms, one is obliged to follow a specific line of thought, dictated by their very usage. Definitions of "ethnic groups" can be quite useful, however, as long as one accepts that they usually involve oversimplified projections of rather perplexing realities. Alexis Alexandris describes the "Pomaks" as " a largely slavophone Balkan Muslim group " which " lives in small settlements in the mountainous Rhodope regions of Thrace near the Bulgarian border, with the biggest concentration situated in Xanthi province where they form $63,4 \%$ of the Muslim population "4. On the other hand, the terms "Roma", "Athingani" and "Gypsies" describe the same group of people. "Athingani" is the formal Greek term used to describe "Gypsies" and was gradually replaced by the term "Roma" in the 1990s. But what do "Pomaks" and "Gypsies" believe about themselves? What is the identity they manifest?

From the outset of this research, I became well aware that it is not an easy task to divide Western Thracian migrants into distinct "ethnic categories". More specifically, my experience in central Athens (Gazi) with those labelled "Muslim Roma" by the Greek state showed that the vast majority identified themselves as "Turks". However, on several occasions, I was told by "Pomak" and "Turkish" informants in Thrace and Athens that the residents of Gazi are "Gypsies" and not "Turks". This was also the case with some "Pomaks" in Athens, who claimed to be "Turks" but were still described as "Pomaks", not only by Greeks but also by their fellow "Pomaks" in Western Thrace5. Thus, the following questions arise : how should one describe a person who claims to be a "Turk" when others describe him as "Gypsy" ? And why do so many "Pomaks" and "Gypsies" claim to be "Turks" ?

I would argue that the answer to the first question is quite simple. The terms "ethnic Turk", "Pomak", "Gypsy" and "Roma", usually found in the literature, are largely products of an academic obsession with dividing people into categories and stamping one ethnic identity on them in order to make sense of their existence. But for Western Thracian migrants in Athens, ethnic identity can be quite situational. It varies according to geography, time, the language of communication, and even the researcher. If that is the case, however, what are the appropriate terms to be used in describing the different segments of the minority population of Western Thrace ? If it is true that "Pomaks", "eth-

\footnotetext{
4 Alexandris (Alexis), "Religion or Ethnicity : The Identity Issue of the Minorities in Greece and Turkey ", in Hirschon (Renée), ed., op.cit., p. 125.

5 Olga Demetriou was amongst the first scholars to deal with the problem of using or not using "Pomakness" as a classification category. See Demetriou (Olga), "Prioritizing "Ethnicities" : The Uncertainty of Pomak-ness in the Urban Greek Rhodoppe ", Ethnic and Racial Studies, 27 (1), 2004.
} 
nic Turks", "Muslim Gypsies" constitute politically loaded labels, it is also true that any possible alternatives to the afore terms could be equally problematic. There is no easy way of avoiding these labels since Pomaks speak of Pomaks, Pomaks of Turks, Gypsies of Pomaks, Turks of Gypsies, and so on. Instead of trying to propose ways of avoiding these labels, I believe that it is more useful to admit from the outset that they exist and have long been in use as political and cultural categories rather than as "objective" realities. Therefore, in the following sections of this article, I will not refrain from using mainstream ethnic categorizations. But I will also try to indicate the context and the identifiers as clearly as possible.

\section{GREECE, TURKEY, CYPRUS AND THE POLITICS OF FEAR}

The answer to the second question is less straightforward. One must first examine Greek and Turkish policies during the second half of the $20^{\text {th }}$ century towards the minority population in Western Thrace. This helps us to understand why the "minority" consciousness currently manifested by many Western Thracian Muslims is one " that since the 1970s has increasingly found its definition in notions of a transnational Turkish identity whose rights are best promoted and guaranteed by the Turkish nation state " 6 . I would argue that this is mainly a result of the inconsistencies characterizing Greek policy towards this minority population. More specifically I will refer to specific state policies and "scientific" campaigns of the second half of the $20^{\text {th }}$ century which aimed at constructing abstract and simplistic categories, creating divisions and taxonomies among people.

From the early 1950 s until 1967, the Greek state actively supported the linguistic Turkification of the local Muslim population, through compulsory minority education 7 . The political rationale behind this policy was that it would

\footnotetext{
${ }^{6}$ Karakasidou (Anastasia), " Vestiges of the Ottoman Past : Muslims under Siege in Contemporary Thrace ", paper presented at the $92^{\text {nd }}$ Annual meeting of the American Anthropological Association, Washington D.C., 17-21 November 1993, p. 5.

7 In accordance with the provisions of the Treaty of Lausanne (1923), Muslim children in Western Thrace attend minority primary schools and learn Turkish as their first language. As a result, many of them are not able to communicate in the Greek language, nor to attain a secondary education, as this usually requires attendance at mainstream Greek schools and fluency in the Greek language. Even fewer are able to pursue a university education, either in Greece or in Turkey. It is also usefull to note that the treaty's provisions are confined to the area of Western Thrace. Thus, the indigenous Muslim communities of the Dodecanese and the Western Thracians living in Athens do not have access to minority education. See Tsitselikis (Konstantinos), To diethnes ke europaiko kathestos prostasias ton glossikon dikaiomaton ton meionotiton ke i Elliniki ennomi taxi (The International and European Status of Linguistic Minority Rights and the Greek Legal Order), Athens : A.N. Sakkoulas, 1996, p. 346 ; U. S. Department of State, Human Rights Report for 1999 - Greece, p. 18, available at http://www.bannet.org/6-3_15gr.htm.
} 
be better for certain segments of the minority population to identify themselves with the Turks of Western Thrace and Turkey, rather than with the Bulgarian communists ${ }^{8}$. Despite the rising tension between the Greek and Turkish communities in Cyprus, as well as the outbreak of violence against the Greeks of Istanbul in 1955, the enemy was Bulgaria and not the nominal NATO ally, Turkey. Subsequently, the border between Greece and Bulgaria became the front line of the NATO/Warsaw Pact confrontation, and was heavily fortified for many kilometres on both sides ${ }^{9}$. Foreigners were denied access to the region, while freedom of movement of the indigenous population was hampered and the region was declared a Military Surveillance Zone, the so-called epitiroumeni zoni ${ }^{10}$. Nevertheless, the rising tension between Greece and Turkey over enosis (unification of Cyprus with Greece) resulted in a change in the Greek policy towards this minority population by the then military dictatorship (1967-1974).

From that time onwards many Greek officials and academics clearly defined the minority population as comprised of three categories of people : the "ethnic Turks", the "Pomaks" and the "Gypsies"11. The main objective of subsequent Greek governments was to cut all ties between the "Pomaks" on the one hand, and Turks and Turkey on the other. This was the most profound change in Greece's official perception of the "Pomaks", as they were now considered Greeks, as well as the beginning of a state-sponsored campaign aiming at proving that the "Pomaks" were islamized Christians of Greek descent ${ }^{12}$. Thus, " the Pomak traditions of cutting the round bread into four pieces and of putting cross-shaped iron bars to windows were interpreted as reminiscent of the Pomaks' Christian times "13. Even racial arguments were put forward. For instance, blood categories were cited in order to prove that the distribution of

\footnotetext{
${ }^{8}$ Brunnbauer (Ulf), "The Perception of Muslims in Bulgaria and Greece : Between the "Self" and the "Other" " Journal of the Institute for Muslim Minority Affairs, 21 (1), April 2001.

9 Poulton (Hugh), " Changing Notions of National Identity among Muslims in Thrace and Macedonia : Turks, Pomaks and Roma " in Poulton (Hugh), Taji-Farouki (Suha), eds., Muslim Identity and the Balkan State, London : Hurst, 1997.

${ }^{10}$ Labrianidis (Lois), " The Impact of the Greek Military Surveillance Zone on the Greek Side of the Bulgarian-Greek Borderlands ", Boundary and Security Bulletin, 7 (2), 1999 ; Labrianidis (Lois), " "Internal Frontiers" as a Hindrance to Development ", European Planning Studies, 9 (1), 2001.
}

${ }^{11}$ Alexandris (Alexis), The Greek Minority of Istanbul and Greek-Turkish Relations 1918-1974, Athens : Centre for Asia Minor Studies, 1992 ; Hidiroglou (Pavlos) The Greek Pomaks and their Relations with Turkey, Athens : Proskinio Editions, 1990.

12 Demetriou (Olga), art.cit., pp. 106-107.

13 Oran (Baskan), "Balkan Muslims : A comparative Study on Greece, Bulgaria, Macedonia and Kosovo ", CEMOTI, (18), 1994. 
blood groups among Pomaks was much more similar to that of Greeks than to that of Turks' ${ }^{14}$.

Paradoxically, retaliatory and discriminatory measures against all members of the minority population of Western Thrace were introduced on a tit-for-tat basis with Turkey ${ }^{15}$. On many occasions, members of this minority population were prevented from obtaining driving licences for tractors and from acquiring the equipment necessary to operate agricultural business. Many of them also lost their land properties as a result of government expropriations. Moreover, members of the minority population of Western Thrace were not allowed to elect their muftis (Muslim jurists) nor to identify themselves as "Turks"16.

These practices continued even after the restoration of democracy in 1974, due to widely spread and deeply embedded fears that " Turkey harbours expansionist designs against Greece ${ }^{17}$. More specifically, Greek policies towards the minority population of Western Thrace aimed at removing the possibility that Greek Thrace would become a "second Cyprus"18. In this context it is interesting to note that the state ban on the word "Turkish" and its derivatives to refer to anything related to the minority population of Western Thrace took place right after the "declaration of independence" of the Turkish Republic of Northern Cyprus in 1983. But the more successive Greek governments tried to prevent the emergence of a single Turkish minority consciousness, the more "Pomaks" and "Gypsies" would transform into "Turks". In other words, a study of Greek minority policies in the 1980 os could easily demonstrate how policies of discrimination provided a base for the unification of highly diverse local communities $^{19}$.

It was only during the last few years that the Greek government radically changed its policy towards the minority population of Western Thrace, tacitly confessing the failures of the past. On 12 March 1990, the then Prime Minister Constantine Mitsotakis (New Democracy - ND), the leader of the opposition Andreas Papandreou (Pan-Hellenic Socialistic Movement - PASOK) and Kharilaos Florakis (Communist Party of Greece - KKE) agreed that " Greece's policy [in Thrace] must be based on the economic and cultural development of the area. We have done nothing to develop the region. There must be strict

\footnotetext{
14 Xirotiris, (Nikolaos), Idiai paratiriseis epi tis katanomis ton syhnotiton ton omadon aimatos eis tous Pomakous (Personal Observations on the Proportional Frequency of Blood Groups among the Pomaks), PhD Dissertation, Salonika : Aristotle University of Salonika, 1971.
}

15 Brunnbauer (Ulf), art.cit., p. 48.

${ }^{16}$ Clogg (Richard), A Concise History of Greece, Cambridge : Cambridge University Press, 2002, p. 206.

${ }^{17}$ Alexandris (Alexis), art.cit., p. 128.

${ }^{18}$ Demetriou (Olga), art.cit., p. 107.

19 See also Aarbakke (Vemund), The Muslim Minority of Greek Thrace, unpublished PhD Dissertation, Bergen : University of Bergen, 2001, pp. 299-338. 
observance of the principle of equal treatment ${ }^{20}$. The new strategy included measures such as greater economic development on the one hand and the settlement of Pontic Greeks arriving from the Soviet Union on the other.

In the 1990s, restrictions of movement were gradually lifted in the mountainous areas of Rhodope. According to Thanos Dokos and Panayotis Tsakonas, Costas Simitis' election as the new leader of the governing PASOK party in 1996 resulted in a change of Greece's strategic priorities ${ }^{21}$. Simitis placed at the top of his agenda Greece's convergence with EU economic prerequisites, and together with the "modernizers' faction" of PASOK questioned the intensifying arms race between Greece and Turkey. A few years later, the then Greek Foreign Minister George Papandreou and his Turkish counterpart Ismail Cem started working towards the preparation of an official rapprochement, which was greatly facilitated by the catastrophic earthquakes of 1999 in Greece and Turkey. The earthquakes became the pretext for a complete reorientation of Greece's foreign policy towards Turkey. It was in this very context that George Papandreou spoke of the right to individual self-identification for members of the minority population in Greek Thrace, and thus initiated a debate over the possible modernization of Greece's minority policies ${ }^{22}$. In 2004, Turkish Prime Minister Recep Tayyip Erdoğan was allowed to visit Western Thrace, the first senior Turkish politician to visit the region since President Celal Bayar's visit in 1952. For many Turkish journalists this visit marked the end of an era of mutual suspicion and the success of the rapprochement ${ }^{23}$.

\section{MIGRATION AND HARDSHIP : FROM ISTANBUL TO LAVRIO}

From the signing of the Treaty of Lausanne onwards successive Greek governments did not contribute to the economic development of the minority population in Western Thrace, following a policy that Alexis Alexandris - a diplomat himself - describes as one of "benign neglect" 24 . As a result, this region remained one of the most underdeveloped in Europe, and daily life became more and more difficult for some of its inhabitants. For them migration to Turkish, German or Greek urban centres emerged as an inevitable choice.

\footnotetext{
${ }^{20}$ Athens News Agency, 13/03/90.
}

${ }^{21}$ Tsakonas (Panayotis), Dokos (Thanos), “ Greek-Turkish Relations in the Early $21^{\text {st }}$ Century. A View from Athens ", in Martin (Lenore), Keridis (Dimitris), eds., The Future of Turkish Foreign Policy, Cambridge : MIT Press, 2004.

${ }^{22}$ Klik, August 1999 ; Flash Radio, 29/07/99.

${ }^{23}$ See for instance " 52 yillik hasret bitti " (The end of 52 years of longing), Sabah, 09/05/04.

${ }^{24}$ Alexandris (Alexis), art.cit., p. 128. 


\section{Emigration to Turkey and Loss of Citizenship}

Emigration to Turkey was not a new phenomenon for the minority population of Western Thrace. According to Tözün Bahçeli, there had been a continuous trend of emigration to Turkey. From 1939 to 1951 approximately 20000 people moved to Turkey, followed by a further 20 ooo during the $1950 \mathrm{~s}^{25}$. However, from the 1960 s onwards the Turkish state did not provide Western Thracian immigrants with residence and work permits, thus making their settlement in Turkey very difficult ${ }^{26}$. The primary reason behind this policy was that the Turkish government wanted to maintain a large minority in the northern part of Greece that it could exploit for political benefit ${ }^{27}$. For the same reason the Turkish authorities tolerated or even supported certain extremist Turkish organizations in Turkey such as the Istanbul-based Solidarity Association of Turks of Western Thrace (Batı Trakya Türkleri Dayanışma Derneği), that called for the independence of Western Thrace. Both Turkish and Greek scholars have written extensively about this policy. Tözün Bahçeli, for instance, states : " The emigration of Muslim Turks from Greece to Turkey has continued to this day. The Turkish government does not encourage such emigration, nor does it ordinarily grant citizenship to emigrants ; however it is feared that this continued emigration would pave the way for the disappearance of the community in Greece ${ }^{28}$.

While Alexis Alexandris states :

At the present moment both Greece and Turkey keep the potentially volatile issue of the minorities at abeyance. But given the Cyprus experience, the Greeks fear that the Turks, taking advantage of the existence of a large Turkish minority at Greece's northeastern panhandle, might be tempted to involve themselves in another adventure on an even wider scale. These apprehensions are reinforced by Ankara's refusal, since 1960, to issue residence and work permits to Muslims with Hellenic nationality. The determination of the Turkish government to maintain a large minority in Greece coupled with the activities of the government-sponsored Association of Mutual Aid for the Turks of Western Thrace, which advocates the "liberation of Western Thrace", added credibility to the Greek fears. ${ }^{29}$

\footnotetext{
${ }^{25}$ Bahçeli (Tözün), Greek-Turkish Relations since 1955, Boulder : Westview, 1990, p. 177.

${ }^{26}$ Aarbakke (Vemund), op.cit., p. 32.

${ }^{27}$ Although the Turkish authorities discourage immigration, they still provide special facilities for Thracian Muslim students wanting to pursue secondary and university education in Turkey. See Bahçeli (Tözün), op.cit., p. 178. According to Anastasia Karakasidou, as many as 8000 minority children were studying in elementary schools, high schools and universities in Turkey in 1993 . See Karakasidou (Anastasia), art.cit., p. 13.

${ }^{28}$ Bahçeli (Tözün), " The Muslim-Turkish Community in Greece: Problems and Prospects n, Journal of the Institute of Muslim Minority Affairs, 8 (1), 1987, p. 112.
}

${ }^{29}$ Alexandris (Alexis), op.cit., p. 315. 
As a result, many emigrants had to apply for the cancellation of their Greek citizenship in order to qualify for a Turkish one, since at that time there was no provision in Turkey for dual citizenship ${ }^{30}$. Others decided to return to Greece. Some of them, however, were now categorized as "stateless" persons31. This is due to the fact that members of the minority who had left Greece, even for a temporary period, had been denied re-entry under Article 19 of the Greek Citizenship Law enacted in 1955. This Article states that :

A person of non-Greek ethnic origin leaving Greece without the intention of returning may be declared as having lost Greek nationality. This also applies to a person of non-Greek ethnic origin born and domiciled abroad. His minor children living abroad may be declared as having lost Greek nationality if both parents or the surviving parent have lost the same. The Minister of the Interior decides in these matters with the concurring opinion of the National Council. ${ }^{22}$

I encountered such cases of "stateless" migrants - mainly Gypsies - while conducting ethnographic fieldwork in Gazi. These people had crossed the Greek borders illegally after the confiscation of their passports by the Greek authorities, and had eventually settled in the Greek capital. All of them were unemployed, without social insurance or healthcare benefits, and unable to communicate in the Greek language.

\section{Emigration to Athens and Social Exclusion}

After the collapse of the military dictatorship in the mid 1970s, Germany became a destination for many Western Thracian migrants33. At the same time, emigration to Athens and the neighbouring industrial areas was directly linked to the demand for cheap, unskilled labour 34 . The slow technological mo-

\footnotetext{
30 Interview with the First Secretary of the Greek Embassy in London, Theodore Theodorou, London, 15 November 2003 ; interview with the Consul General of Greece in Istanbul Alexis Alexandris, Istanbul, 18 March 2004 ; interview with Mehmet in Istanbul, 10 March 2004; interview with Ömer in Istanbul, 13 March 2004.

31 The late Alternate Foreign Minister Yiannos Kranidiotis estimated stateless persons at 500 on 27 October 1998 (for more information, see Greek Helsinki Monitor, Minority Rights Group - Greece, Report about Compliance with the Principles of the Framework Convention for the Protection of National Minorities, 18 September 1999, available at (http://www.ceehr.euv-frankfurt-o.de/hr/state.htm〉). Nowadays less than one hundred of such former Greek citizens live in Greece as "stateless" persons.
}

$3^{2}$ The Greek government repealed this article of the Citizenship Law on 11 June 1998. The repeal, however did not apply retroactively.

33 Gerasimos Notaras claims that western Thracian Muslims had not been allowed to migrate to Germany during the military regime of 1967-1974 (see Notaras (Gerasimos), " I anomogeneia tou plithismou. Ena chronio provlima " (The Population's Lack of Homogeneity. A Chronical Problem), in Academy of Athens, I anaptixi tis Thrakis (The Development of Thrace), Athens : Akadimia Athinon, p. 46.

34 Petrakd (Georgia), “ I agora ergasias sto Lavrio kata tin periodo 1956-87 " (Labour Market in Lavrio during the Period 1956-1987), Enimerotiko deltio tou institoutou ergasias tis GSEE, 30-31, 1993, pp. 58-72 ; Petrakd (Georgia), " Sti Xanthi ke sto Lavrio: Taxikes diastaseis tou meionotikou stin Ellada ", Sinchrona Themata, 65, 1997, p. 85 . 
dernization of Greek industry and agriculture created a pressing demand for a flexible workforce. Those who decided to migrate to Athens in the 1970 s and 1980 selonged to the lower social and economic strata of Thrace's minority population. Large numbers of minority workers were employed in the industrial areas of Lavrio, Markopoulo, Aspropirgo, and Eleysina35. Like many other migrants coming to Athens from other parts of Greece and from Egypt ${ }^{36}$, these workers did not have stable jobs. Their readiness to undertake short term or contract employment that often entailed dangerous or unhealthy working conditions helped characterize their minority identity 37 .

Most of the migrants were recruited in Thrace by a French mining company (later named EMMEL) based in Lavrio, a suburb of Athens, in order to undertake work that local workers usually refused ${ }^{38}$. EMMEL's then chief of personnel explained this practice in an interview to Georgia Petraki. It is interesting to note the different terms used by the interviewee to describe Western Thracian migrants. He refers to them as "Greeks of Turkish origin" (official terminology), "Muslims" and "Mohammedans", using these terms interchangeably. In particular, the use of the term "Mohammedans" reminds us of the work of Edward Said, and indeed reveals a widespread belief that Islam is really " based upon an idea of apostolic succession culminating in Muhammad 39 .

We had no choice but to launch recruitment campaigns in Komotini [ $\left.{ }^{4}\right]$. The first Greeks of Turkish origin were brought to Lavrio by the French company in 19741975. We had people working for us who had contacts with Muslims. They were trying to convince them to come and work, we also offered them a house. They had also tried to bring people from other regions too, but it was not possible. Thus they had no choice but to bring Mohammedans. There was only a shortage in smelters. ${ }^{41}$

Many migrants also worked in the dynamite production sector of a nearby military plant (PYRKAL). After a series of fatal accidents, most of them resigned and sought work in a textile factory called Aigaio, also located in Lavrio. From 1978 to 1986, Aigaio hired more than 600 workers from Western Thrace, who in

35 Ibid.

${ }^{36}$ From the mid 1970 s onwards factories located at Lavrio were also hiring immigrants from Egypt. See Petraki (Georgia), Apo to horafi sto ergostasio. I diamorfosi tou viomihanikou proletariatou sto sighrono Lavrio (From the Field to the Factory. The formation of an Industrial Proletariat in Modern Lavrio), Athens : Tipothito-Giorgos Dardanos, 2002, pp. 80-81.

37 Ibid.

${ }^{38}$ Petraki (Georgia), "Sti Xanthi ke sto Lavrio " (art.cit.), p. 84.

39 See Said (Edward), Orientalism, London : Vintage, 2003, pp. 66, 280-281.

$4^{\circ}$ Komotini (Gümülcine in Turkish) is a town located in Western Thrace.

${ }^{41}$ Petraki (Georgia), " I agora ergasias sto Lavrio " (art.cit.), p. 71. 
most cases settled in Lavrio with their families. Even though it is not to be assumed that all of the workers were members of the minority population, Georgia Petraki does specify that the vast majority of them were "Greek Muslims" ${ }^{2}$.

All of these migrants were working in low-ranking positions, for example as cleaners and transport workers. None of them was ever promoted to a more responsible post 43 . Apart from Lavrio, many migrants worked during the $1980 \mathrm{~s}$ in factories and industries in other heavily industrialized suburbs of Athens, such as Aspropirgos, Drapetsona, Eleysina and Halkida. The limitation of their employment to that of hard physical jobs, in conjunction with squalid living conditions, differentiated these workers from the local Greek workers. Children of the minority families rarely attended classes at school. In most cases they had to look after their younger siblings or even to work in grocery stores and small factories that were still using child labour. In the early 1990s, Greek anti-racist organizations initiated a campaign for the creation of a Turkish school in Lavrio for the education of the migrants' children. This initiative, however, was doomed to failure. Local authorities strongly opposed this idea and organized protests and public meetings. The most common objection to the establishment of a Turkish school in Lavrio was that such a development would encourage minority migrant workers to settle permanently in the area, thus downgrading the quality of daily life 44 .

In the late 1980 s, economic crisis led to the closure of most of the factories in which Western Thracian migrants used to work. As a result, some returned to Western Thrace, some moved to other parts of Athens, while others decided to remain in Lavrio. Nowadays the last group numbers only a few families. However, this migration movement to Lavrio was a significant event in the history of Western Thracian migration to the greater metropolitan area.

\section{THE TURKISH NEIGHBOURHOOD IN GAZI : SPACE, MEMORY AND THE MUSLIM EVERYDAY}

From the outset of this research, I was particularly interested in the Muslim population of Gazi 45 , which nowadays is estimated at somewhere between 3000 and 4000 people. Having read transcripts from several parliamentary debates over the establishment of a central mosque in Athens, I had

\footnotetext{
$4^{2}$ Petraki (Georgia), op.cit., pp. 80-81.

43 Petraki (Georgia), " Sti Xanthi ke sto Lavrio " (art.cit.), p. 85.

44 Ibid.

45 Gazi was named after a gas plant which was in operation until the mid 1980s.
} 
learned that some MPs had suggested Gazi as an ideal place for its construction, because of its high Muslim concentration ${ }^{46}$. However, during these debates, the origins of these Muslims were never clarified. Were they immigrants from the Middle East or migrants from Western Thrace?

The visitor of Gazi cannot help noticing the peculiarities of the locality. Fashionable clubs and restaurants are located next to old refugee houses with enormous satellite dishes. In the daylight, one also notices many coffeehouses in which people are speaking Turkish, drinking tea instead of coffee, and watching Turkish television. In my effort to make sense of the local geography and to find answers to my questions, I asked Mehmet, a dear friend from Western Thrace, to put me in touch with a Muslim from Gazi. In a few days time, I was introduced to Kuru.

Kuru is the so-called 'president' of the Muslims of Gazi and the founder of the Society of Thracians - Allilegii ("Solidarity"). He is considered to be one of the most educated members of that community, since he is a primary school graduate. He also seems to be among the few who have not adopted a second Christian name (like Antreas/Nazmin, Antonis/Hasan, Makis/Hüseyin, Savas/Mustafa, etc.), after settling in Athens 47 . I conducted with him some of the most fascinating interviews of my fieldwork research. In contrast to other Muslims of Gazi who were extremely suspicious about people interested in their community, Kuru spoke openly about the history of his migration to Athens and his religious life :

I came to Athens in 1985, when I was 25. Before that I was living in Gümülcine [Komotini], where I grew up. At that time, I was facing serious economic problems. I had worked for many years with other Muslims as a sailor, but I was tired of it. Fortunately, in 1985 I was approached by people working for the social services, who told us that they could find a job for us in Athens, in the public sector. I had nothing to lose, so I came with my family. I was hired as a porter in a branch of the National Bank of Greece at Syntagma Square $\left[{ }^{8}\right]$, where I continue to work to this

${ }^{46}$ The possibility of building a central mosque in Athens is under discussion since the 1970s. In 2000, a project for the construction of a large-scale central mosque and Islamic Cultural Centre in Peania, an area $20 \mathrm{~km}$ east of the centre of Athens, has been adopted by the Greek government. Greek officials have only discussed this matter with Arab diplomats, thus completely excluding local Muslims. The Greek Ministry for Foreign Affairs - not the ministry for Education and Religious Affairs - has been drafting a statute in co-operation with the ambassadors of Morocco, Jordan and the PLO representative. Meanwhile King Fahd of Saudi Arabia has agreed to fund the construction of both the mosque and the cultural centre. As expected, this governmental initiative was met with fierce opposition from MPs, clerics of the Orthodox Church and the local population. Typical arguments against the construction of the mosque are that it will encourage large numbers of Muslims to settle in the area, or that the central mosque will be visible from the airplanes approaching Athens international airport. See Antoniou (Dimitris), "Muslim Immigrants in Greece : Religious Organization and Local Responses ", Immigrants and Minorities, 22 (2-3), 2004.

47 This practise has been well documented in various newspaper articles. See for instance " Mousoulmaniki kaimi sto Gazohori " (Muslim Blues in Gazohori), Eleftherotypia, 15/04/94.

$4^{8}$ Syntagma Square is located in Central Athens, opposite the Parliament. 
day. I was clever. Others from Gümülcine who were also offered jobs decided not to come to Athens. They were too afraid that they would have to wear a cross, that they would become Christians.

I was not afraid of that. I knew from the very beginning that this would not happen. I was telling them, "Aren't we Greek citizens ? Why should we be afraid ? " When I went back to Gümülcine the next summer, all these people found out not only that I was still a Muslim, but also that I had a good job and that I had bought an apartment with an interest-free loan from the government.

Of course I was not the only one offered a job in the public sector. Many of my friends have also found jobs in banks, hospitals, etc. When people in Gümülcine found out that we have a good life here, they decided to move to Athens too. But they could not find jobs. So they moved to these old houses. They were stupid... They did not say "yes" from the very beginning. Now they complain. They say to me, "You have a job, a big apartment, you are rich ". And I reply, "You morons. The state $\mathrm{f}$...ed [49] once and it is not going to be f...ing forever ".

Kuru Hüseyin's words were indeed revealing as regards a state policy that was encouraging metadimotefsi, the resettlement of members of the minority population in other parts of Greece, a policy that started in the early 1980s. Part of this policy was to offer to members of the minority population employment in the public sector and to provide them with interest-free loans. According to some Greek journalists the only condition was that the migrants transfer their voting rights from Western Thrace to Athens. The objective behind this policy thus becomes obvious : to weaken minority political participation in the area of Western Thrace ${ }^{50}$. However, Yiannis Kapsis, Deputy Minister for Foreign Affairs from 1982 to 1988 , described the policy of metadimotefsi during an interview in a different way :

This policy was my idea. My goal was to encourage the integration of Western Thracian Muslims into Greek society. The situation in Western Thrace was quite problematic not because of the discriminatory measures against the Muslims which Antreas Papandreou had already agreed with me to ban - but mainly due to the local mafias that were established over the years. These local mafias, consisting of both Christians and Muslims, were making enormous amounts of money through the continuation of some discriminatory measures against Muslims [ ${ }^{51}$.

49 In this context, the word " $f$... " means assistance and support.

5o Sevasti Troubeta and Gerasimos Notaras make mention of this policy. See Trubeta (Sevasti), Kataskevazontas taftotites gia tous Mousoulmanous tis Thrakis. To paradeigma ton Pomakon ke ton Tsiganon (Constructing Identities for the Muslims of Thrace. The Case of the Pomaks and the Gypsies), Athens : Kritiki / Minority Groups Research Center, 2001, p. 52 ; Notaras (Gerasimos), art.cit., p. 49 ; Trimis (Dimitris), "I ensomatosi sto Gazi i stis piges tou ratsismou " (The Integration in Gazi or in the Sources of Racism), Sholiastis, 36, 1986, p. 23.

${ }^{51}$ During our interview, Yiannis Kapsis referred for instance to the existence of illegal channels through which members of the minority could acquire tractors and hunting guns with an additional cost. 
The only thing we could offer to people willing to settle in different parts of Greece was a job. Nothing else. We never asked them to transfer their voting rights. Take for example the existing community in Drapetsona. To this day most of them vote in Komotini. 52

Through these interviews, I discovered that the Gazi community consists of two different groups. In addition, I was able to explain why some of the migrants in Gazi and the neighbouring areas of Votanikos and Keramikos are in a far better economic situation than others. These are the individuals who did not hesitate to accept the afore-mentioned offers made to them by the state. In contrast to what Kuru claims, in my research I found that most of the migrants who live in the old refugee houses are those who moved to Athens before 1982, when Yiannis Kapsis became Deputy Minister for Foreign Affairs. In my examination of this second group of migrants I was surprised to discover that, in most cases, the families were in fact renting the old refugee houses which seemed in such poor condition. A family typically rents one or two rooms, and shares a courtyard, bathroom, and kitchen facilities with another family 53 . This housing arrangement and practice clearly reflect the poor economic situation and unemployment characterizing this particular group of Western Thracian migrants.

More specifically the main types of employment that they can find are jobs as street vendors, second-hand dealers, scrap merchants and builders. According to various studies more than two-thirds of the women are unemployed, while men work, on average, less than 15 days per month 54 . Many of them have no social insurance or healthcare benefits. Recent educational initiatives, such as the establishment of an intercultural school in the district of Votanikos and the organization of afternoon literacy classes by volunteers and non-governmental organizations, have pledged to improve the life of the Muslim residents in this area55. Despite these pledges, considerable time must pass before decent living conditions can be established. A report issued by the Greek Ministry of Health regarding the Muslim migrants living in Gazi states :

Some of these migrants, who do not know how to read or communicate in the Greek language, are inevitably enclosed within Gazi boundaries, incapable of

52 Interview with Yiannis Kapsis, 20 January 2006.

53 For some additional information regarding minority statistics in Gazi in the early 1980s, see Tseloni (Andromahi), "Neoellines pisti tou Islam stin kardia tis Athinas " (Neo-Hellenes Believers in Islam in the Heart of Athens), Prosanatolismoi, 72 (1-2), 1984, pp. 38-41.

54 Chtouris (Sotiris), Psimmenos (Iordanis), Tzelepogou (Flora), " Muslim Voices " in the European Union : Greece, available at 〈http://www.aegean.gr/sociology/gso/en/muslim-voices.htm〉.

55 Lytra (Vasiliki), « Nicknames and Teasing : A Case Study of a Linguistically and Culturally Mixed Peer Group in an Athenian Primary School ", in Androutsopoulos (Jannis), Georgakopoulou (Alexandra), eds., Discourse Construction of Youth Identities, Amsterdam : Benjamins, 2003 ; as well as the documentary by Marianna Economou, The School (2001). 
working outside.... Cases of social exclusion are constantly multiplying. This is a result of unemployment, poverty and despair.... Cases of alcoholism and drug use, especially among the youth, are constantly rising. Thus a general rise in criminality is inevitable.... The identification of Greek Muslims with foreigners by those possessing feelings of religious fanaticism results in racism and xenophobia. 56

This report, however, does not elaborate further on the agents of "racism and xenophobia". Who is afraid of the xenos, the "foreigner" ? Is it only the Greeks of Gazi and Votanikos ? The majority of the Muslim migrants living in Gazi are Turkish-speakers ; for them, speaking Turkish offers a higher social status and constitutes a proof of their Turkish identity. Most of them, however, speak a mix of Turkish and Romany and manifest from time to time a Turkish-Gypsy identity. All of them are discriminated against and labelled "Gypsies" by other Western Thracian migrants in Athens. Similarly, Turkish-speaking Muslim Gypsies living in Gazi are considered Gypsies and not Turks by most members of the minority population in Western Thrace, as noted by Olga Demetriou : " By the time I actually arrived in Komotini, I had met with Gümülcinelis [Turkish-speaking inhabitants of Komotini/Gümülcine] who had migrated to London and Turkey and had been informed that the migrants in Athens are Gypsies and not Turks " 57 .

The Muslim population of Gazi has attracted the attention not only of the Greek Ministry of Health but also of the Turkish press. Thus, an extended article on the religious life of the Muslims of Gazi appeared in Zaman, a Turkish daily newspaper. The article incorporates interviews with local Muslims on the problems they are facing in their daily practice of Islam, as well as their religious dependence on Western Thrace and Turkey :

Because there is no imam to perform the funeral rituals, our deceased have been travelling an $800 \mathrm{~km}$ distance to Gümülcine [Komotini] or to İskeçe [Xanthi] for year... There is no one who would teach our religion to our children. I know two sure [58], that is all I grew up with, my children perhaps know one. But their children neither know Turkish nor their religion. We bought books from Turkey with our own money and we made photocopies, but it is not enough... Nowadays we only listen to the Glorious Qur'an from cassettes, because we do not know how to read it. We also chant the mevlid [59] from cassettes which we bring from Turkey. ${ }^{60}$

56 " Gazi : Pireos ke eksathliosis gonia " (Gazi : Pireos and the Corner of Misery), Eleftherotipia, 10/o4/o2.

57 Demetriou (Olga), art.cit., p. 14.

$5^{8}$ Chapters of the Qur'an.

59 The mevlid is a panegyric poem in honour of the Prophet. The mevlid chanted by Western Thracian Muslims as part of the celebrations for the birthday of Muhammad or in religious meetings held in memory of a deceased person was composed by Süleyman Çelebi (d. 825/1421). See Pekolcay (Ayşe Neclâ), " Mevlid ", in Islâm Ansiklopedisi, İstanbul : Milli Eğitim Bakanlığı, 1960, vol. 8.

60 "Atina'daki cami tartışması semboller savașına dönüștü " (The Debate over the Athens Mosque has Turned into a War of Symbols), Zaman, 11/03/03. 
The appearance of this article in the Turkish press urged me to inquire into the religious life of that particular locality of Athens. Having known that some Western Thracian Muslims in other parts of the capital had established their own mescits (prayer halls), I was interested in discovering the Muslim everyday in Gazi. My findings were indeed surprising. The Gazi community lacks a place of worship. This was explained to me on economic grounds by one of my informants, who claimed that the cost of maintaining a mescit is very high ${ }^{61}$. When I asked his reasons for not attending mescits supported by a Western Thracian organization called Filotita, I received a surprising answer : "They are Pomaks, they are of a different race. They hang around with the Arabs. We don't " 62 .

\section{THE COFFEE HOUSE IN PLATEIA VATHIS : SYMBOLIC AND SOCIAL WORLDS}

These initial contacts with the Western Thracian Muslims of Gazi generated a series of questions regarding the identity, history of migration to Athens, and religious organization of the people often described as Pomaks. However, what had become clear was that the Gazi community maintained very limited contacts with the other Western Thracian Muslims of the capital, and had created their own imagery to describe the Pomaks of Athens. The Pomaks were considered to be of a "different race", capable of "hanging out with the Arabs", and in a better state both economically and religiously. All of them were supposedly living in Plateia Vathis, only one and a half kilometres away from Gazi.

Many years ago, Sotiria Bellou, a famous rebetiko singer, sang a song entitled Plateia Vathis (Vathis Square). The song was named after a downgraded area in central Athens and related the hard life of the workers living there. It also addressed the socio-economic inequalities characterizing life in Athens. Plateia Vathis, even though quite central, has never constituted a destination for wealthy Athenians, mainly due to its reputation as an area with a high concentration of brothels and criminals. It is for this reason that, in another verse of the song, the composer invites his friend to visit Plateia Vathis in order to " witness the kind of life he lives " (ela na mathis stin Plateia Vathis ti zoi perno), the life of the poor. In this sense, little has changed over the last few years in Plateia Vathis, as it continues to attract the new poor of the capital : migrants from Albania, the former Soviet Union, South Asia and Western

${ }^{61}$ Interview with Mehmet in Gazi, 15 July 2004.

62 Ibid. 
Thrace. This last group of migrants is the one Muslims in Gazi had been referring to : the Pomaks.

Pomak social life in Plateia Vathis is organized around coffee houses and restaurants, most of them named after villages in Rhodope. It is in these places that one gets a strong sense of Pornak public life. My first encounters with this community took place in a coffee house/restaurant called Kentavros. The establishment of Kentavros follows the pattern of the old kafeneia, coffeehouses divided along lines of origin, named after villages or regions outside Athens, and which used to serve as a meeting place for the sintopites. These were Greeks originating from the same village, who had migrated to the capital and who were still trying to integrate into the tough urban life of the 1950 s and 1960 s. In this respect Kentavros is one of the last region-based kafeneia of Athens, even though it was established quite recently, in the mid 1980s.

Kentavros is a place solely frequented by men who came to Athens during the last twenty years. For them, emigration to neighbouring Turkey did not seem to be a viable option, as the country was facing severe economic problems, and they had been informed by their networks in Istanbul that there were few jobs available. Such migration is in most cases a seasonal and male experience. Women are usually left behind in the villages to take care of the children, the elderly, the animals, fields and houses. However, there are some cases of whole families migrating to urban centres. According to Domna Michail, those who migrate with their families are usually " long term migrants who have stopped any kind of productive activity in the villages and if some day they come back to their village permanently they choose other occupations than that of cultivating tobacco ${ }^{63}$.

These people seem to comprise the vast majority of Western Thracian migrants. In Athens they also reside in another downgraded area, Akadimia Platonos, because of the availability of cheap housing. Some of them also reside in the suburbs of Nea Makri, and Eleysina, where they usually work as builders, agricultural labourers or unskilled manual workers in small factories and shipyards. Through my contacts with the people of Kentavros I discovered that a large number of Pomaks work in the shipyards of Perama, when work is available. Otherwise, they visit friends and family in Holland and Germany who also happen to work in shipyards. Through these networks they are able to find part-time employment in the same line of work as they pursue when in Greece.

In the Pomak coffee houses of Plateia Vathis, many stories are told about how difficult work in the shipyards can be and how inevitable it is that young men should seek employment far from their birthplace. All these narratives re-

63 See Michail (Domna), "Migration, Tradition and Transition among the Pomaks in Xanthi (Western Thrace) ", LSE PhD Symposium on Social Science Research on Greece, London, June 21, 2003. 
veal a great deal of nostalgia for the Pomak villages of Rhodope, as well as a fear for the consequences that a prolonged stay in the capital might have. Life in these mountainous villages is always portrayed as better. The food tastes better, women look better, the regions' climate makes people healthier. In contrast, life in Athens is mostly viewed as a mere necessity, accompanied by daily challenges. As one of my informants put it, the greatest challenge of all " is not to forget who you are, what your language and religion are ". In this context my informant expressed a concern very similar to the one expressed by the Gazi resident to Zaman's reporter.

Undoubtedly, the coffee houses constitute a safe environment, where people feel able to manifest a different linguistic and religious identity. One of the first things I noticed during my fieldwork research was that in the coffeehouses people were not hesitating to address each other with their real Muslim names. This is certainly not the practice in the outside world where Pomak migrants feel obliged to adopt a second Christian name. Daily communication can take place not only in Greek but also in the Pomak dialect, as well as in Turkish. It is in this environment again that people can openly discuss their plans to return to their villages for the celebration of major Muslim festivals. However, linguistic preferences do not necessarily reveal an ethnic allegiance, nor does the celebration of Ramadan reveal a great degree of devotion. To this day I find it very difficult to talk about a single Pomak identity and to define Pomakness at a macro level. Over the years I came across many individuals who manifest a Pomak identity and have totally different understandings of its content. Against this background, I will now shift my focus of interest from coffeehouses to individuals and discuss the case of Mehmet İmam and the activities of a Muslim organization called Filotita.

\section{MUSLIM ORGANIZATIONS IN ATHENS : THE CASE OF FILOTITA}

Identifying the existing Western Thracian Muslim organizations in the Greek capital and determining their number and size is an immensely difficult task, since most of them are not officially registered and sometimes operate for a short period of time. Even though I have studied only the case of two Western Thracian Muslim organizations, some of my informants have also mentioned the existence of several others, less vocal and active ${ }^{64}$. These func-

64 Apart from the Pan-Hellenic Federation in Support of the Muslims in Greece - Filotita and the Society of Thracians - Allilegii, whose existence I have personally verified, some of my informants have also referred to the Pan-Hellenic Federation of Greek Muslims; the Union of Muslims from Evro (based in Drapetsona, Piraeus) ; the Educational and Cultural Club of Muslims (based in Evia). 
tion along with many other ethnic-based organizations established by Muslim immigrants ${ }^{65}$. In most cases, both their members and their governing boards are of poor educational background and have a very limited knowledge of Greek.

In this respect, the Pan-Hellenic Federation in Support of the Muslims in Greece - Filotita (Friendship) - is an exception to the rule. This federation was established by Pomak university graduates in 1997 and constitutes an important development in the history of Muslim presence in the capital in general and Western Thracian migration to Athens in particular. This initiative reflects not only the manner in which some members of the Pomak community consider their residence in Athens as a permanent settlement, but also a shift in their perceptions of the capital. For them, Athens no longer represents the distant capital of a repressive state, but a leading migratory destination which attracts thousands of Muslims from different parts of the world. What is also interesting to note concerning Filotita's founding members is that they articulate an identity discourse that differs from the one of the Turkish minority elite in Western Thrace, and distance themselves both from the official Greek and Turkish rhetoric regarding the Muslim minority. These Pomaks may well be the Athenian equivalent of the new Pomak elite described by Olga Demetriou in Komotini ${ }^{66}$.

\section{« Our Muslim Brothers ! : Filotita's Manifesto}

Filotita's somewhat confused ideology is reflected in its manifesto, which was written in Turkish by its president Mehmet Imam, and was circulated both in villages in Rhodope and in Athens.

Our Muslim Brothers!

As is known to all of you, for long years the minorities living in Greece have been deprived of their social, cultural and religious rights.

For that reason, and as we constitute the minorities living in this country, it was decided on 7 November 1997 to establish an association in order to win our rights and to give life to the philosophy of the principle of equality which exists in modern democracies and countries, and the decision was approved by the authorized court and gained official status on 24 November 1997.

Our aim is to achieve the unity of individual minority members, regardless of ethnic origin, and to provide social benefits.

Our Association's name is Filotita. Its main principles are social and humanist [ones]. Our aim is to take human love and brotherhood as our base, to obtain the support even of non-Muslims, and to take our place in line with contemporary Europe.

\footnotetext{
65 See Antoniou (Dimitris), art.cit.

${ }^{66}$ Demetriou (Olga), art.cit., p. 113.
} 
Obtaining our religious, linguistic, cultural and social rights in an uninterrupted manner and in the way provided by humane principles and international law, and bringing them down into everyday life, liberates us from pressure [ ${ }^{6} 7$. Filotita aims at doing a small contribution to participation, human values, brotherhood, impartiality, love of nature and a tomorrow free of anxiety. Our purpose is to encompass all people facing problems in Greece. [Filotita] claims to struggle in order to achieve our rights in a democratic way, to prove our existence and to fulfil the religious requirements in the way our exalted God demands. In this [endeavour] we have and will have the biggest support from you. Your existence and your support will be our greatest strength.

If there had been an institution which would meet our demands, the existence of such an organization would not even have been considered. Because historical conditions and documents show that those regions in which minorities reside have been intentionally left underdeveloped, non-integrated and alienated from their cultural structure. We think that our ethnic identity is a decisive reason for this. The areas whose cultural structure and level of education is the lowest in Greece are those where the minorities reside. Filotita wants to break the narrow circle and to play an active role in beautiful perspectives in which all of us will live together, to integrate people without discrimination, to abolish fragmentation and, on the basis of humanistic principles, to bring together people from all religious beliefs.

To achieve our unity and to make our presence felt as a single voice is a right which is granted to us under the laws and by the Universal Declaration of Human Rights and we have to use these to the very end.

As a result of the needs of minorities, Filotita has emerged from amidst these minorities. It defends human love, togetherness, and the virtues of living together. For many years minorities in Greece have been neglected and received second class treatment. Minorities throughout Greece should from now on defend their cause and understand the character of their own structure.

The basic rule of living humanly is to defend your right. The provision of having your own religion is to worship freely.

Our Muslim brothers, we want to see you in our unity and togetherness. ${ }^{68}$

The manifesto was clearly written by a non-native Turkish speaker. The sentences are long and complicated ; they are difficult to follow, to understand and to translate. For poorly educated readers, Filotita's manifesto is impressive. The usage of words like "minorities", "rights", "democracy" and "law" is extensive. It aims to capture the attention of an audience which for many years was discriminated against by the Greek state, and also to describe the beginning of

67 The translation of this sentence is based on the correction of what I assumed to be a number of typographical errors.

${ }^{68}$ Filotita, « Mülüman Kardeșlerimiz ! n (Our Muslim Brothers !), undated leaflet. 
a new era marked by the establishment of Filotita. At the same time, complicated sentences underline the authority of the author.

As he mentioned in an interview with me, Mehmet Imam is " a native speaker of the Pomak language " while he learned Turkish at school ${ }^{69}$. He claims to have been among the first from the village of Ehinos/Șahin to break the "narrow circle" (dar çember) he refers to in the above manifesto, by finishing high school in Istanbul and pursuing university education at Istanbul University. After an unsuccessful attempt to become a local MP on a PASOK ticket in Western Thrace, he settled in Athens, where he established Filotita. Mehmet İmam, like many other Pomaks of Athens also distances himself from the official rhetoric of both Greece and Turkey regarding the minority population of Western Thrace. He defines himself as "Pomak", "Rhodopean", "European" and "Greek citizen", but never as "Greek" or "Turk".

\section{Filotita as an Intermediary between Western Thracian Muslims, Muslim Migrants and the Greek Society ?}

To what extent the ideals expressed in the manifesto correspond to Filotita's activities in Athens ? For Mehmet İmam, one of the major problems characterizing the minority population of Western Thrace was a lack of proper representation ("If there had been an institution which would meet our demands, the existence of such an organization would not even have been considered "). According to him, Filotita's members soon realized that the only way to gain lobbying power with the Greek government was to try to represent all Muslims living in Greece. It is perhaps for this reason that he refers to "minorities" in plural and addresses his "Muslim Brothers", thus stressing a common religious identity. In this respect, Filotita has been quite successful since the majority of its members consists of Bangladeshi, Pakistani, Egyptian, Sudanese, Algerian, Albanian, Philippine and Burmese immigrants rather than Western Thracian Muslims. Most of the latter immigrated to Greece in the 1990s, and reside in underdeveloped neighbourhoods of the capital where also most of the Western Thracian migrants reside ${ }^{70}$. Religion is not the only link between the two groups, who share common social characteristics and face similar problems. Muslims in Athens are usually males, aged between 25 and 44, unskilled and underpaid manual workers with limited knowledge of the Greek language ${ }^{71}$. Their settlement in Athens has led to conditions already experienced in other European capitals : weak individual rights, social exclusion and the emergence of racist reactions from the local majority population.

\footnotetext{
69 Interview with Mehmet Imam, 2 October 2003.

${ }^{70}$ Antoniou (Dimitris), art.cit.

${ }^{71}$ Ibid.
} 
As one could read in the manifesto, Filotita expresses a will to assist not only members of the minority population of Western Thrace, but also to " encompass all people facing problems in Greece ". Its projects have focused on the creation of a religious infrastructure for the capital's Muslims, by organizing Qur'an courses for Muslim children, lobbying for the establishment of a Muslim cemetery and supporting the establishment of several "multi ethnic" mescits in the city centre ${ }^{72}$. Such places of worship are also frequented by Pomaks, wholike the Muslim residents of Gazi - lack a mescit of their own. According to Mehmet Imam Filotita has also created and implemented local development programmes for the teaching of the Greek language to the Muslims of the capital and has played an active role in assisting Muslim illegal immigrants to legalize their presence in Greece, by providing them with free legal advice. Through the regular appearances of some of its members in TV shows, it has tried to promote a national dialogue aimed at counteracting "Islamophobia". In this context it is particularly important to note Mehmet Imam's active involvement in the debate over the establishment of a central mosque in Athens, which operated across local, national and international levels 73 .

Despite its efforts, Filotita receives no assistance from state bodies and organizations. Some limited assistance is received from Greek leftists, who can be viewed as the "non-Muslims" described in the manifesto. The latter play an important role in processes of negotiation and intercultural communication between Filotita's members on the one hand, and the Greek government and society on the other. This is particularly the case with a university lecturer at a university in Athens. For this member the reason behind volunteering for such an organization is not conversion to Islam but a strong determination to fight against the state's minority policies and the social exclusion faced by the migrants. It seems that for that member, Filotita represents the ultimate enemy of a nationalistic state, church and society : a Muslim organization established in Athens by individuals of undefined ethnic origin.

\footnotetext{
${ }^{72}$ Since there are no Muslim cemeteries in Athens, Western Thracian Muslims are forced to transport their deceased back to Thrace. This fact has resulted into a serious economic burden, which is usually impossible for family members to meet. In this situation the entire community must raise funds in order to cover the expense of this transfer. Nevertheless Theodore Theodorou of the Greek Embassy in London claimed that the müftülüks (the Mufti Offices) of Western Thrace usually undertake the financial cost of such transportation. Interview with Theodore Theodorou, London, 15 November 2003.
}

${ }^{73}$ Mehmet Imam used this opportunity to express his own concerns in regard to the building of the central mosque. He considered that a central mosque far away from the city center cannot serve the devotional needs of the capital's Muslim population. To his mind Athenian Muslims are fully capable of raising funds and establishing their own mosques as long as the Greek state and the Orthodox Church allow them to do so. See Foreign Correspondent, Being Greek, $A B C$, broadcasted on the $13^{\text {th }}$ July 2004 . 


\section{CONCLUSION : FROM LOCAL TO GLOBAL}

The settlement of Western Thracian Muslims in Athens provides a useful long-term case study of internal migration. Despite the long history of this migration and its significance, it has not attracted the attention of many scholars. This is perhaps a result of the interaction between academic and official discourses on Greek national space, which portray only one region as impure : that of Western Thrace. Such regions are always considered most interesting for scholars, who themselves by no means constitute a homogenous group. In the case of Western Thrace, some authors - let us call them international relations experts and historians - strive to prove how mistaken the Turkish state is in accusing Greece of human rights violations in the area and to provide evidence of the Greekness of the Pomaks. Others - let us call them anthropologists - are extremely critical, and rightly so, of Greek state policies, and attempt to challenge mainstream ethnic categorizations such as "Pomaks", "Turks", "ethnic Turks", "Athingani" and "Gypsies". In these analyses, however, the reasons for the problematic situation in Western Thrace and the subsequent migration movements to Athens are only traced to Greco-Turkish minority policies, thus overlooking the role of individual agency. In this respect, Yiannis Kapsis' interview is particularly useful, since it underlines a factor which is often forgotten, that of local economic interests. In other words, it is not only Greece and Turkey that have manipulated the minority population of Western Thrace for their own ends, but also locals, both Christian and Muslim, profiting from these states' mutual antagonism.

Having said this, I would agree with the vast majority of scholars that the minority population of Western Thrace is far from being homogenous. The migrants discussed in this article constitute diverse and fragmented communities, who, in many cases, reproduce problems and attitudes originating from their situation in Western Thrace. In examining aspects of their presence in Athens, I have observed perceptions and manifestations of multiple and situational identities, resulting to some extent from conflicting Greek and Turkish state policies. Within this context, one can understand why scholars conducting research in Thrace are informed that some migrants living in Athens are "Gypsies" and not "Turks". It is again this context that explains why one of my interlocutors from Gazi describes Filotita's members as from a "different race", and why Mehmet İmam identifies himself as "Pomak" but never as either "Greek" or "Turk".

To argue exclusively, however, that the Western Thracian migrants of Athens are divided along lines of language, culture and origin is surely not a particularly novel insight. I find it more sensible to investigate the new dynamics created by the migrants' settlement in Athens, and to ask : what changes when Western Thracian Muslims settle in the metropolis ? 
For many years, the Muslim residents of Western Thrace were directly influenced by the provisions of the Treaty of Lausanne on the one hand, and by the Greco-Turkish conflict on the other. Having moved to Athens, however, they are now in a different position. Their settlement in the metropolis signified an almost automatic loss of interest in them on behalf of both states as well as a loss of educational provisions. The migrants are viewed neither as "fifth columnists" nor as potential allies. Over the years, they have attempted to adjust to conditions in their respective localities, dealing with illiteracy, acute hardship, economic marginality, political neglect and nostalgia for the places they had left. The use of both Christian and Muslim names, the enormous satellite dishes in Gazi and the establishment of coffeehouses all represent the migrants' efforts not only to integrate into the life of the metropolis, but also to distance themselves from it, maintaining links with their homeland, its languages and traditions. Furthermore, this reveals a preference for re-establishing familiar patterns and overcoming the personal alienation and social disintegration into which many other migrants and refugees have sunk.

Thus the migrants' arrival in a city, which for the last fifteen years has offered shelter to thousands of other Muslim immigrants, has posed many new challenges. This in turn has undoubtedly created new dynamics among them. Allilegii and Filotita, for instance, constitute entities that developed independently of similar organizations in Western Thrace. They are organized around different leaders and address different needs. In this paper I have focused more on the case of Filotita, not only because it is the most active and vocal Muslim organization of the capital, but also because its function signifies a transition from the "local" to the "global". What I refer to as "local" is the GrecoTurkish conflict and its legacy of painful memories. The "global" on the other hand is associated with challenges such as illegal migration and the new Muslim presence in the "West". Filotita's determination to represent all its "Muslim Brothers" regardless of ethnic background and to participate in the debate over the establishment of a Central Mosque has, in a way, helped it to overcome the regional boundaries so clearly symbolized by the coffee houses in Plateia Vathis. It is undoubtedly the Muslim organizations' positioning in this latter context that will determine their significance in years to come. 